\title{
Involvement of potassium channels in amitriptyline and clomipramine analgesia
}

\author{
Nicoletta Galeotti, Carla Ghelardini *, Alessandro Bartolini \\ Department of Pharmacology, University of Florence, Viale G. Pieraccini 6, I-50139 Florence, Italy
}

Received 6 October 1999; accepted 25 May 2000

\begin{abstract}
The effect of the administration of modulators of different subtypes of $\mathrm{K}^{+}$channels on antinociception induced by the tricyclic antidepressants amitriptyline and clomipramine was evaluated in the mouse hot plate test. The administration of the voltage-gated $\mathrm{K}^{+}$channel blocker tetraethylammonium $(0.01-0.5 \mu \mathrm{g}$ per mouse i.c.v.) prevented antinociception induced by both amitriptyline (15 $\mathrm{mg} \mathrm{kg}^{-1}$ s.c.) and clomipramine ( $25 \mathrm{mg} \mathrm{kg}^{-1}$ s.c.). The $\mathrm{K}_{\text {ATP }}$ channel blocker gliquidone (0.1-1.0 $\mu \mathrm{g}$ per mouse i.c.v.) prevented antinociception produced by amitriptyline and clomipramine whereas the $\mathrm{K}_{\mathrm{ATP}}$ channel openers minoxidil $(10 \mu \mathrm{g}$ per mouse i.c.v.) and pinacidil $(25 \mu \mathrm{g}$ per mouse i.c.v. $)$ potentiated tricyclic antidepressant-induced analgesia. The administration of the $\mathrm{Ca}^{2+}$-gated $\mathrm{K}^{+}$channel blocker apamin (0.1-1.0 ng per mouse i.c.v.) completely prevented amitriptyline and clomipramine analgesia. At the highest effective doses, none of the drugs used induced behavioural side effects or impaired motor coordination, as revealed by the rota-rod test, spontaneous motility or inspection activity, as revealed by the hole board test. The present results demonstrate that central antinociception induced by amitriptyline and clomipramine involves the opening of different subtypes of $\mathrm{K}^{+}$channels (voltage-gated, $\mathrm{K}_{\text {ATP }}$ and $\mathrm{Ca}^{2+}$-gated) which, therefore, represent a step in the transduction mechanism of tricyclic antidepressant analgesia. @ 2000 Elsevier Science Ltd. All rights reserved.
\end{abstract}

Keywords: $\mathrm{K}^{+}$channel; Analgesia; Clomipramine; Amitriptyline; Tricyclic antidepressants; Minoxidil; Pinacidil; Gliquidone; Apamin; Tetraethylammonium

Tricyclic antidepressants have long been known to exert analgesic activity in laboratory animals (Murua and Molina, 1991; Goldstein et al., 1990; Acton et al., 1992) and to provide analgesia for a variety of neuropathic and headache pain syndromes in humans regardless of the presence of depression (Richeimer et al., 1997). The analgesic effect of tricyclic antidepressant drugs seems unrelated to their antidepressant action since the doses used for analgesia are lower than those considered effective in the treatment of depression (Acton et al., 1992). Furthermore, clinical trials have shown that the response to tricyclic antidepressants of patients suffering from chronic pain syndromes with coexisting diagnosis of depression is similar to that of patients without documented depression (Richeimer et al., 1997).

Clomipramine and amitriptyline, as well as other tri-

* Corresponding author. Tel.: +39-55-4271312; fax: +39-554271280.

E-mail address: ghelard@ server1.pharm.unifi.it (C. Ghelardini). cyclic antidepressants, are inhibitors of serotonin reuptake. The subsequent increase of endogenous serotonin in the synaptic cleft has been supposed to be responsible for the increase in the pain threshold of mice either directly (Galeotti et al., 1995), or through activation of the opioid system (Sacerdote et al., 1987).

The stimulation of 5-HT receptors can affect several types of $\mathrm{K}^{+}$channels in central neurones (Bobker and Williams, 1990). Electrophysiological studies have shown that a number of different types of $\mathrm{K}^{+}$channel currents exist in mammalian neurones (Christie, 1995). $\mathrm{K}^{+}$channels can be classified by their mechanism of activation-inactivation. Among them are the voltagegated $\mathrm{K}^{+}$-channel currents which have been classified as fast-activating A-type currents and slowly inactivating delayed-rectifier type currents (Catterall, 1988; Jan and Jan, 1989; Mathie et al., 1998). Other $\mathrm{K}^{+}$channels can be modulated by neurotransmitters interacting with Gprotein-coupled receptors (Brown and Birnbaumer, 1990; Brown, 1990). G proteins can modulate different types of $\mathrm{K}^{+}$channels through a direct effect on the ion 
channel or through an enzymatic step leading to the generation of cytoplasmic second messengers (Brown, 1990; Hille, 1994). Various pharmacological compounds can modulate these channels. Tetraethylammonium (TEA) blocks different types of $\mathrm{K}^{+}$channels in neurones including $\mathrm{Ca}^{2+}$-activated and voltage-dependent $\mathrm{K}^{+}$channels (Cook and Quast, 1990; Halliwell, 1990). Apamin was reported to block specifically currents through the $\mathrm{Ca}^{2+}$ activated $\mathrm{K}^{+}$channels (Cook, 1988). Sulphonylureas such as gliquidone, block $\mathrm{K}_{\mathrm{ATP}} \mathrm{K}^{+}$channels in neurones whereas minoxidil and pinacidil open the same type $\left(\mathrm{K}_{\mathrm{ATP}}\right)$ of $\mathrm{K}^{+}$channel (Edwards and Weston, 1993; Longman and Hamilton, 1992).

Central $\mathrm{K}^{+}$channels appear to be involved in the modulation of pain perception. The central administration of $\mathrm{K}^{+}$channel openers, such as diazoxide, minoxidil, lemakalim and cromakalim, has been reported to produce antinociception in laboratory animals (Welch and Dunlow, 1993; Narita et al., 1993) and to potentiate the enhancement of the pain threshold produced by opioid and $\alpha_{2}$-adrenoceptor agonists (Vergoni et al., 1992; Ocaña et al., 1996). Furthermore, treatment with $\mathrm{K}^{+}$channel blockers, such as sulphonylureas, 4-aminopyridine and tetraethylammonium, prevented the antinociception induced by $\alpha_{2}$-adrenoceptor, $\mathrm{GABA}_{\mathrm{B}}$ and opioid receptor agonists (Ocaña and Baeyens, 1993; Raffa and Martinez, 1995).

Recently, it has been reported that the administration of an antisense oligonucleotide which selectively inhibited the expression of the gene coding for the voltage-gated $\mathrm{K}^{+}$channel $\mathrm{mKv} 1.1$, prevented analgesia induced by tricyclic antidepressants (Galeotti et al., 1997). Since little is known about the intracellular effectors involved in the mechanism of analgesic action of tricyclic antidepressants, we decided to investigate further the role of $\mathrm{K}^{+}$channels in the enhancement of the pain threshold induced by the tricyclic antidepressant drugs amitriptyline and clomipramine.

\section{Methods}

\subsection{Animals}

Male Swiss albino mice (23-30 g) from Morini (San Polo d'Enza, Italy) were used. The mice were housed 15 per cage. The cages were placed in the experimental room 24-h before the test, for adaptation. The animals were fed a standard laboratory diet and tap water ad libitum and kept at $23 \pm 1^{\circ} \mathrm{C}$ with a 12 -h light/dark cycle, light on at 7 a.m. Animals were used once only. All experiments were carried out in accordance with the European Communities Council Directive of 24 November 1986 (86/609/EEC) for experimental animal care.

\subsection{Intracerebroventricular injection technique}

Intracerebroventricular (i.c.v.) administration was performed under ether anaesthesia, according to the method described by Haley and McCormick (1957). Briefly, during anaesthesia, mice were grasped firmly by the loose skin behind the head. A $0.4 \mathrm{~mm}$ external diameter hypodermic needle attached to a $10 \mu$ l syringe was inserted perpendicularly through the skull and no more than 2 $\mathrm{mm}$ into the brain of the mouse, where $5 \mu \mathrm{l}$ were then administered. The injection site was $1 \mathrm{~mm}$ to the right or left from the midpoint on a line drawn through to the anterior base of the ears. Injections were performed into the right or left ventricle randomly. To ascertain that the drugs were administered exactly into the cerebral ventricle, some mice $(20 \%)$ were injected with $5 \mu$ of diluted 1:10 India ink and their brains examined macroscopically after sectioning. The accuracy of the injection technique was evaluated and the percentage of correct injections was 95 .

\subsection{Hot plate test}

O'Callaghan and Holtzman (1975) described the method adopted. Mice were placed inside a stainless steel container, which was set thermostatically at $52.5 \pm 0.1^{\circ} \mathrm{C}$ in a precision water-bath from $\mathrm{KW}$ Mechanical Workshop, Siena, Italy. Reaction times (s), were measured with a stopwatch before and 15, 30, 45 and 60 min after amitriptyline and clomipramine administration. The endpoint used was the licking of the fore or hind paws. Those mice scoring less than 12 or more than 18 $\mathrm{s}$ in the pre-test were rejected $(30 \%)$. An arbitrary cutoff time of $45 \mathrm{~s}$ was adopted.

The licking latency values reported in Figs. 2, 3 and 5 were evaluated in relation to the maximum analgesic effect of amitriptyline and clomipramine, which was 30 min after administration.

\subsection{Hole-board test}

The hole board test set-up utilises a $40 \mathrm{~cm}$ square plane with 16 flush-mounted cylindrical holes (diameter $3 \mathrm{~cm}$ ) distributed 4 by 4 in an equidistant, grid-like manner. The mice were placed in the centre of the board one by one and left to move about freely for a period of 5 min each. Two photoelectric beams, crossing the plane from mid-point to mid-point of opposite sides, thus dividing the plane into 4 equal quadrants, automatically signalled the movement of the animals on the surface of the plane. Miniature photoelectric cells, in each of the 16 holes, recorded the exploration of the holes (head plunging activity) by the mice. 


\subsection{Rota-rod test}

The apparatus consisted of a base platform and a rotating rod of $3 \mathrm{~cm}$ diameter with a non-slippery surface. This rod was placed at a height of $15 \mathrm{~cm}$ from the base. The rod, $30 \mathrm{~cm}$ in length, was divided into 5 equal sections by 6 disks. Thus up to 5 mice were tested simultaneously on the apparatus, with a rod-rotating speed of 16 r.p.m. The integrity of motor coordination was assessed on the basis of endurance time of the animals on the rotating rod according to the method described by Kuribara et al. (1977). One day before the test, the animals were trained twice. On the day of the test only the mice that were able to stay balanced on the rotating rod between 70 and 120 s (cut-off time) were selected for testing. Performance time was measured before and 15,30 and $45 \mathrm{~min}$ after s.c. administration of the investigated compounds.

\subsection{Drugs}

The following drugs were used: clomipramine (Anafranil, Ciba Geigy, Basel, Switzerland), amitriptyline (Sigma, Milan, Italy), minoxidil, pinacidil, apamin, tetraethylammonium (RBI, Milan, Italy); gliquidone (Boehringer Ingelheim, Milan, Italy), D-amphetamine (De Angeli, Rome, Italy).

Drugs were dissolved in isotonic $(\mathrm{NaCl} 0.9 \%)$ saline solution, with the exception of pinacidil, that was dissolved in a water and dimethyl sulphoxide (DMSO) $(3: 1)$ vehicle, immediately before use. Drug concentrations were prepared in such a way that the necessary dose could be administered in a volume of $5 \mu \mathrm{l}$ per mouse by i.c.v. injection and $10 \mathrm{ml} \mathrm{kg}^{-1}$ by s.c. injection.

Apamin, gliquidone, minoxidil, pinacidil and TEA were injected i.c.v. $15 \mathrm{~min}$ before the test. The drug administration schedule was chosen on the basis of preliminary experiments in which the time-course and the dose-response curves in the hot-plate test for every compound were determined.

\subsection{Statistical analysis}

All experimental results are given as the means \pm SEM. An analysis of variance (ANOVA), followed by Fisher's Protected Least Significant Difference (PLSD) procedure for post-hoc comparison, was used to verify the significance of differences between two means. Data were analysed with the StatView software for the Macintosh.

\section{Results}

\subsection{Effect of TEA on tricyclic antidepressant antinociception}

The effect produced by TEA, a blocker of voltagegated $\mathrm{K}^{+}$channels, on the enhancement of the pain thres- hold produced by amitriptyline (15 $\mathrm{mg} \mathrm{kg}^{-1}$ s.c.) and clomipramine ( $25 \mathrm{mg} \mathrm{kg}^{-1}$ s.c.) was investigated in the mouse hot-plate test. The administration of TEA (0.001$0.5 \mu \mathrm{g}$ per mouse i.c.v.) produced a dose-dependent prevention of both amitriptyline (Fig. 1, panel A) and clomipramine (Fig. 1, panel B) antinociception.

\subsection{Effect of $K_{A T P}$ channels modulators on tricyclic antidepressant antinociception}

The effect produced by the blocker (gliquidone) and the openers (minoxidil, pinacidil) of $\mathrm{K}_{\mathrm{ATP}}$ channels was investigated on the enhancement of the pain threshold produced by amitriptyline ( $15 \mathrm{mg} \mathrm{kg}^{-1}$ s.c.) and clomipramine ( $25 \mathrm{mg} \mathrm{kg}^{-1}$ s.c.).

The administration of the $\mathrm{K}_{\mathrm{ATP}}$ channel blocker gliquidone (0.01-1.0 $\mu \mathrm{g}$ per mouse i.c.v.), $15 \mathrm{~min}$ before the mouse hot-plate test, prevented antinociception induced by amitriptyline (Fig. 2, panel A) and clomipramine (Fig. 2, panel B) in a dose-dependent manner.

Both $\mathrm{K}_{\mathrm{ATP}}$ channel openers minoxidil $(10 \mu \mathrm{g}$ per mouse i.c.v.) and pinacidil ( $25 \mu \mathrm{g}$ per mouse i.c.v.), injected 15 min before the test, potentiated the antinociceptive activity of all the investigated tricyclic antidepressants (Fig. 3). A lower dose of minoxidil (1 $\mu \mathrm{g}$ per mouse i.c.v.) and pinacidil (5 $\mu \mathrm{g}$ per mouse i.c.v.) was ineffective (Fig. 3).

\subsection{Effect of the $\mathrm{Ca}^{2+}$-activated $\mathrm{K}^{+}$channel blocker apamin on tricyclic antidepressant antinociception}

The effect produced by the $\mathrm{Ca}^{2+}$-activated $\mathrm{K}^{+}$channel blocker apamin on the enhancement of the pain threshold induced by amitriptyline ( $15 \mathrm{mg} \mathrm{kg}^{-1}$ s.c.; Fig. 4, panel A) and clomipramine (25 $\mathrm{mg} \mathrm{kg}^{-1}$ s.c.; Fig. 4, panel B) was investigated in mouse using the hot-plate test.

Apamin (0.01-1.0 ng per mouse i.c.v.), injected 15 min before the test, dose-dependently prevented the antinociception induced by the tricyclic antidepressants investigated as illustrated in Fig. 4.

Regression lines showing the dose-dependent inhibition of amitriptyline and clomipramine antinociception produced by increasing concentrations of TEA, gliquidone and apamin, are shown, as insets, respectively in Figs. 1, 2 and 4. The licking latency values reported were evaluated in relation to the maximum analgesic effect of amitriptyline and clomipramine, which occurred $30 \mathrm{~min}$ after administration.

\subsection{Effect of $\mathrm{K}^{+}$channels modulators on pain threshold}

The effect on the pain threshold produced by the modulators of $\mathrm{K}^{+}$channels used was investigated by using the mouse hot plate test. As reported in Table 1, modulators of voltage-gated (TEA), $\mathrm{Ca}^{2+}$-gated (apamin) 

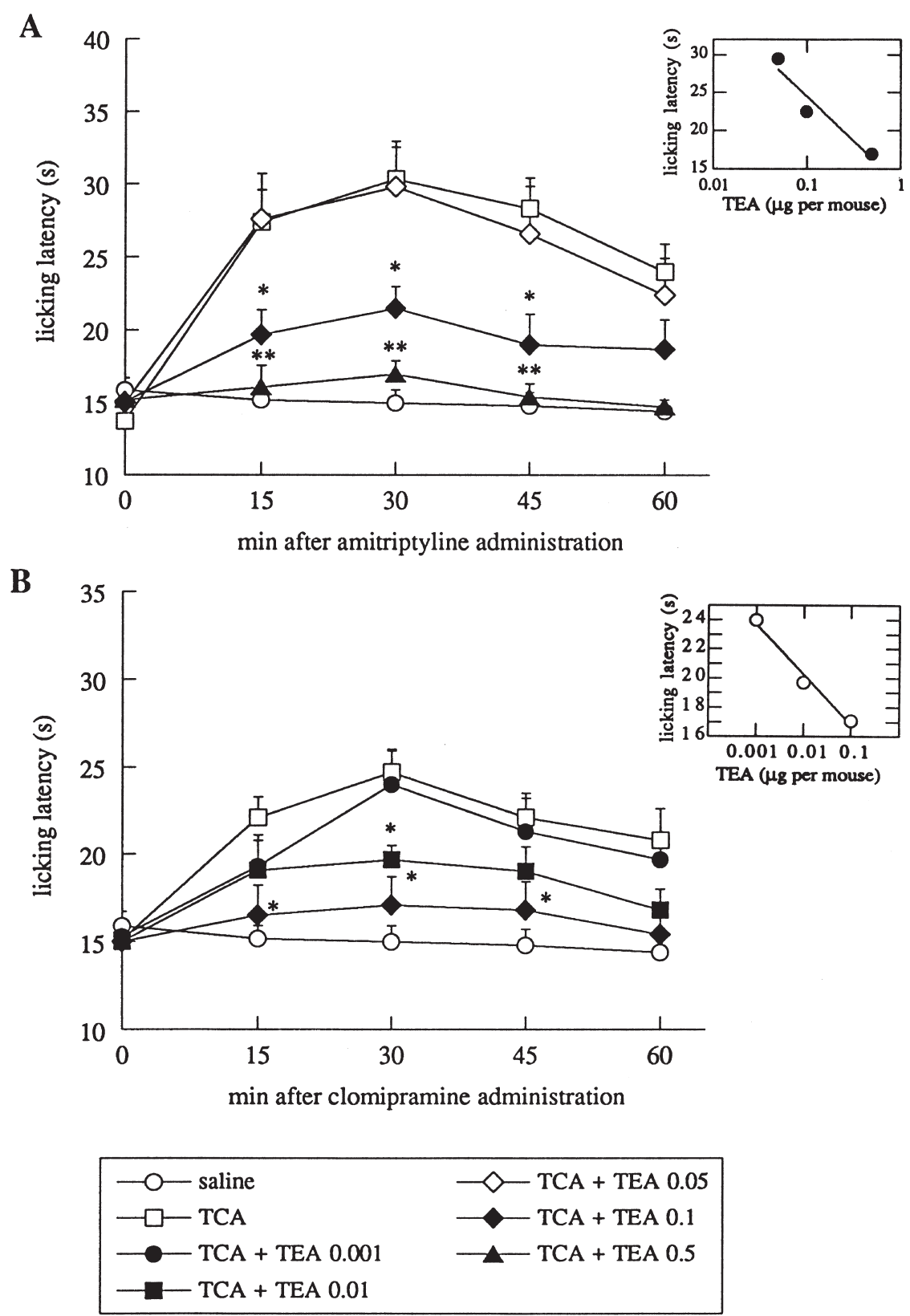

Fig. 1. Prevention of analgesia induced by amitriptyline $\left(15 \mathrm{mg} \mathrm{kg}^{-1}\right.$ s.c.; panel A) and clomipramine $\left(25 \mathrm{mg} \mathrm{kg}^{-1} \mathrm{s.c.}\right.$; panel B) by increasing concentrations of TEA (0.001-0.5 $\mu \mathrm{g}$ per mouse i.c.v.) in the mouse hot-plate test. Mice were i.c.v. injected with saline or TEA 15 min before the test. Vertical lines give SEM; there were 10-17 mice per group. ${ }^{*} p<0.05, * * p<0.01$ in comparison with corresponding analgesic drug-treated mice. Inset: dose-dependent prevention of amitriptyline $\left(15 \mathrm{mg} \mathrm{kg}{ }^{-1}\right.$ s.c., panel A) and clomipramine $\left(25 \mathrm{mg} \mathrm{kg}^{-1}\right.$ s.c., panel B) analgesia by increasing concentrations of TEA. The licking latency values were recorded $30 \mathrm{~min}$ after TCAs administration.

and $\mathrm{K}_{\mathrm{ATP}}$ channels (gliquidone, minoxidil, pinacidil) modified the licking latency values of mice when given alone, having no hyperalgesic or analgesic effect.

The doses reported in Table 1 were the highest effective doses investigated for each compound.

\subsection{Effect of antidepressants and $K^{+}$-channel modulators on mouse behaviour}

Amitriptyline and clomipramine, at the doses used in the present work, elicited their antinociceptive effect without changing the gross behaviour of the mice. Similarly, $\mathrm{K}^{+}$channel modulators exhibited their ability to modulate enhancement of the pain threshold produced by tricyclic antidepressants without inducing any behavioural side effect.

All of the investigated compounds failed to alter the motor coordination of the mice as revealed by the rotarod test (Table 2). The rota-rod endurance time of mice treated with amitriptyline $\left(15 \mathrm{mg} \mathrm{kg}^{-1}\right.$ s.c.), clomipramine $\left(25 \mathrm{mg} \mathrm{kg}^{-1}\right.$ s.c.), TEA ( $0.5 \mu \mathrm{g}$ per mouse i.c.v.), apamin (1.0 ng per mouse i.c.v.), gliquidone (1.0 $\mu \mathrm{g}$ per 
A

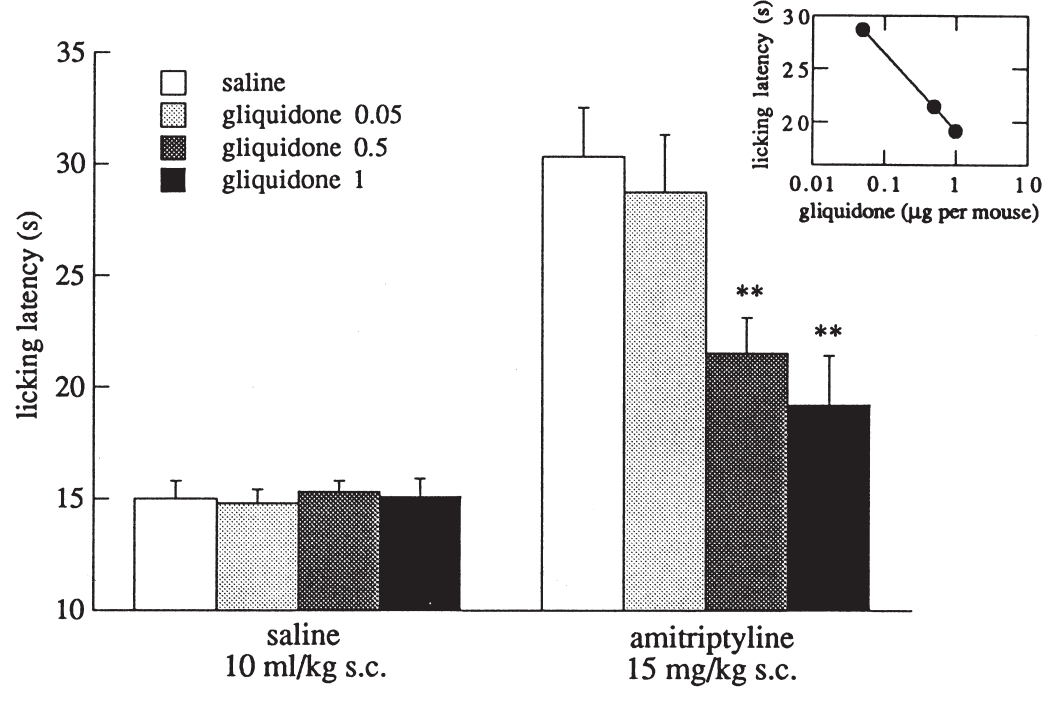

B

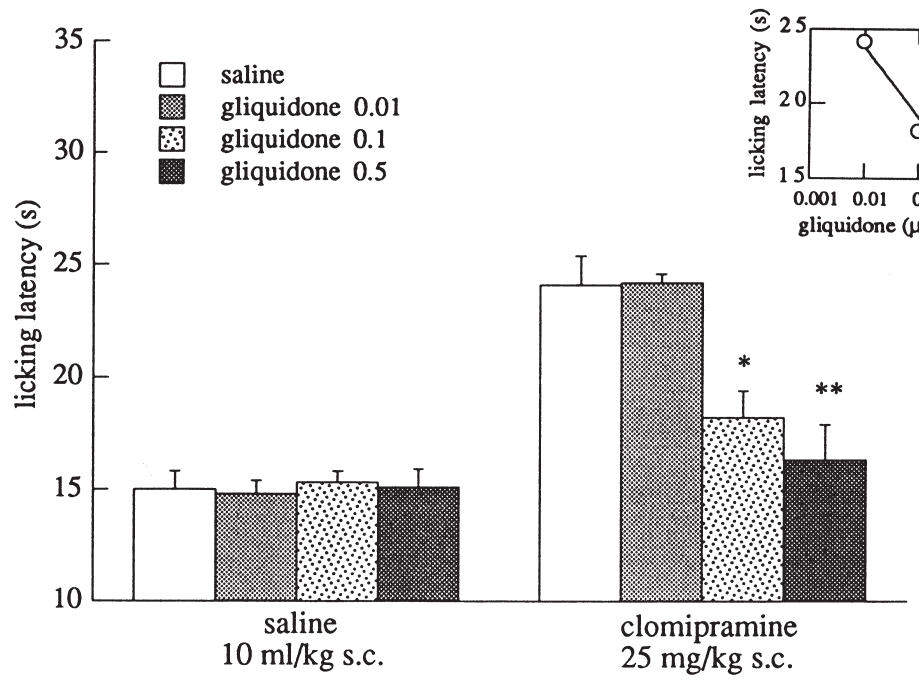

Fig. 2. Prevention of analgesia induced by amitriptyline $\left(15 \mathrm{mg} \mathrm{kg}^{-1}\right.$ s.c.; panel A) and clomipramine $\left(25 \mathrm{mg} \mathrm{kg}^{-1} \mathrm{s.c.}\right.$.; panel B) by increasing concentrations of gliquidone $(0.01-1.0 \mu \mathrm{g}$ per mouse i.c.v.) in the mouse hot-plate test. Mice were i.c.v. injected with saline or gliquidone 15 min before the test. The licking latency values were evaluated $30 \mathrm{~min}$ after administration of TCAs. Vertical lines give SEM; there were 12-19 mice per group. $* p<0.05, * * p<0.01$ in comparison with corresponding analgesic drug-treated mice. Inset: dose-dependent prevention of amitriptyline (15 $\mathrm{mg} \mathrm{kg}^{-1}$ s.c., panel A) and clomipramine ( $25 \mathrm{mg} \mathrm{kg}^{-1}$ s.c., panel B) analgesia by increasing concentrations of gliquidone.

mouse i.c.v.) and minoxidil (10 $\mu \mathrm{g}$ per mouse i.c.v.), was not modified in comparison with saline-treated mice (Table 2). Similarly, the administration of pinacidil (25 $\mu \mathrm{g}$ per mouse i.c.v.) did not alter the motor coordination in comparison with the vehicle-treated mice (Table 2). By contrast, higher doses of amitriptyline $\left(30 \mathrm{mg} \mathrm{kg} \mathrm{m}^{-1}\right.$ s.c.) and clomipramine ( $45 \mathrm{mg} \mathrm{kg}^{-1}$ s.c.) impaired rotarod performances of mice (Table 2).

Furthermore, the concentrations of amitriptyline, clomipramine, TEA, apamin, gliquidone, minoxidil and pinacidil which did not alter motor coordination, were also unable to modify either inspection activity (Fig. 5, panel A) or spontaneous motility (Fig. 5, panel B) of mice as revealed by the hole board test.

\section{Discussion}

The results reported in the present work indicate that modulation of neuronal $\mathrm{K}^{+}$channels represents an essential step in the induction of analgesia by tricyclic antidepressants. Our results demonstrate that the administration of $\mathrm{K}^{+}$channel blockers (TEA, apamin, gliquidone) prevented the enhancement of mouse pain threshold produced by the tricyclic antidepressants amitriptyline and clomipramine. In contrast, the $\mathrm{K}^{+}$channel openers (minoxidil, pinacidil) potentiated the tricyclic antidepressant-induced analgesia. Therefore, the $\mathrm{K}^{+}$ channel functionality appears fundamental in the mech- 


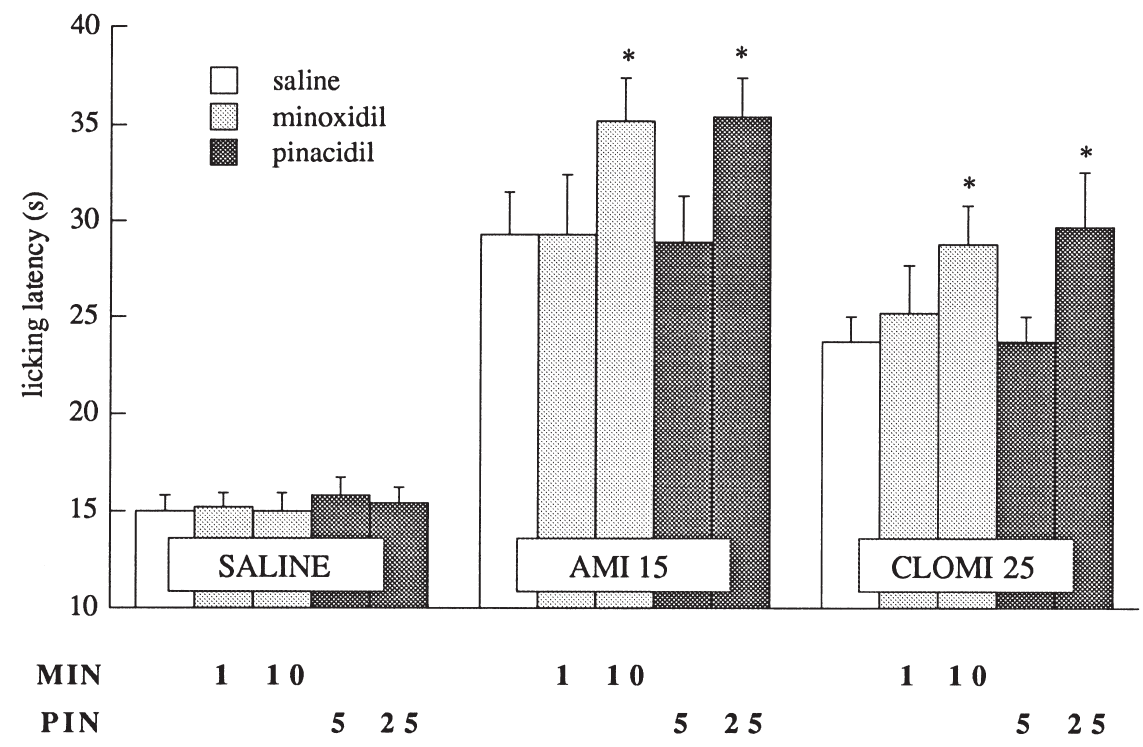

Fig. 3. Potentiation of analgesia induced by amitriptyline (AMI) $\left(15 \mathrm{mg} \mathrm{kg}^{-1}\right.$ s.c.; panel A) and clomipramine (CLOMI) (25 mg kg $\mathrm{kg}^{-1} \mathrm{s.c}$.; panel B) by minoxidil (1-10 $\mu \mathrm{g}$ per mouse i.c.v.) and pinacidil (5-25 $\mu \mathrm{g}$ per mouse i.c.v.) in the mouse hot-plate test. Mice were i.c.v. injected 15 min before the test. The licking latency values were evaluated $30 \mathrm{~min}$ after administration of TCAs. Vertical lines give SEM; there were 12-17 mice per group. ${ }^{*} p<0.05$ in comparison with corresponding analgesic drug-treated mice.

anism of analgesic action of amitriptyline and clomipramine.

At concentrations used in the present work, neither the $\mathrm{K}^{+}$channel blockers (TEA, gliquidone, apamin), nor the $\mathrm{K}^{+}$channel openers (minoxidil, pinacidil) used, modified the licking latency values of mice in comparison with control groups. The lack of effect of TEA, gliquidone and apamin agrees with results of studies in which these compounds did not modify the nociceptive threshold against thermal noxious stimuli (Welch and Dunlow, 1993; Raffa and Martinez, 1995; Welch et al., 1995) excluding that the prevention of amitriptyline and clomipramine antinociception is due to a hyperalgesic effect of the $\mathrm{K}^{+}$channel blockers used. The administration of the $\mathrm{K}^{+}$channel opener minoxidil has been reported to induce antinociception in the tail flick test, but this effect was detectable only at doses higher than those employed in the present study (Welch and Dunlow, 1993). We can, therefore, rule out that the potentiation of tricyclic antidepressant antinociception could be subsequent to an enhancement of the pain threshold produced by the minoxidil and pinacidil. The lack of modification of the pain threshold by $\mathrm{K}^{+}$channels modulators at concentrations able to prevent tricyclic antidepressant analgesia, might also indicate that $\mathrm{K}^{+}$channels of neurones involved in the modulation of pain perception are not tonically activated.

The present results indicate the involvement of voltage-gated $\mathrm{K}^{+}$channels in the mechanism of analgesic action of tricyclic antidepressants. The administration of TEA, a blocker of voltage-gated $\mathrm{K}^{+}$channels (Cook and Quast, 1990; Halliwell, 1990) dose-dependently prevented the antinociception induced by amitriptyline and clomipramine. These results are in agreement with previous data in which the lack of expression of the voltagegated $\mathrm{K}^{+}$channel mKv1.1 by i.c.v. administration of a specific antisense oligonucleotide, prevented the antinociception induced by both amitriptyline and clomipramine (Galeotti et al., 1997).

The important role played by $\mathrm{K}_{\mathrm{ATP}}$ channels in the capability of amitriptyline and clomipramine to enhance the pain threshold is also shown. The administration of gliquidone, a potent blocker of ATP-dependent $\mathrm{K}^{+}$channels $\left(\mathrm{K}_{\mathrm{ATP}}\right)$ (Amoroso et al., 1990), prevented the antinociception produced by the tricyclic antidepressants amitriptyline and clomipramine. Pretreatment with minoxidil and pinacidil, openers of neuronal $\mathrm{K}_{\mathrm{ATP}}$ channels (Longman and Hamilton, 1992), potentiated the enhancement of the pain threshold produced by the above-mentioned analgesic compounds. These results suggest that opening of the $\mathrm{K}_{\mathrm{ATP}}$ channels underlies the antinociception induced by both tricyclic antidepressants investigated. In the light of these considerations, it is plausible to suggest that the potentiation of amitriptyline and clomipramine antinociception induced by minoxidil and pinacidil may occur because these compounds facilitate the opening of $\mathrm{K}_{\mathrm{ATP}}$ channels induced by tricyclic antidepressants.

The intracellular mechanism of analgesic action of amitriptyline and clomipramine involves the activation of a pertussis toxin (PTX)-sensitive G-protein, since their analgesia is prevented by the i.c.v. administration of PTX (Galeotti et al. 1996, 1997). PTX-sensitive Gproteins $\left(G_{i}\right)$ are responsible for modulation of ionic conductance through a direct interaction with the ion channel and/or by lowering intracellular cyclic AMP levels 

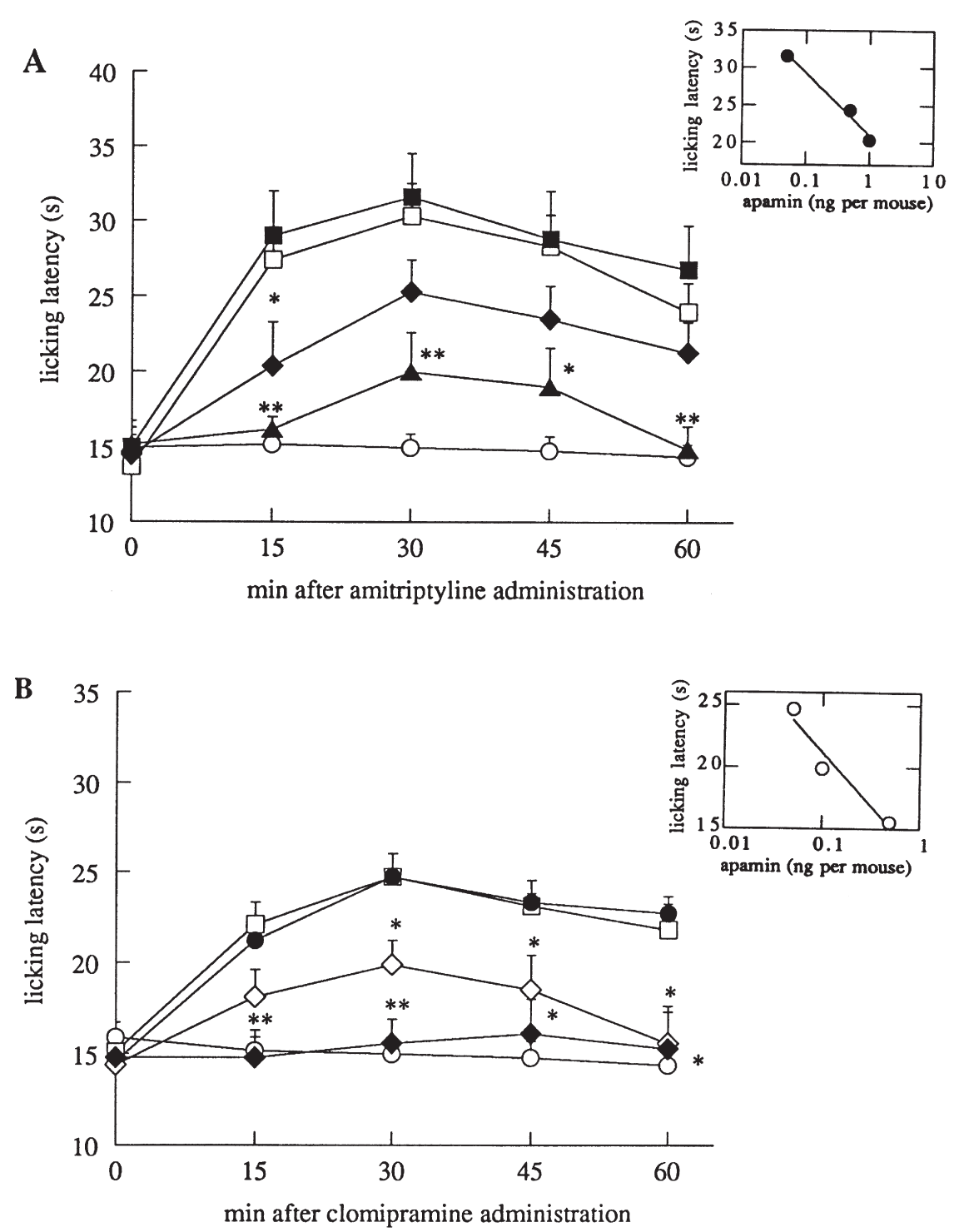

\begin{tabular}{ll|}
$-\mathrm{O}$ saline & $\checkmark \mathrm{TCA}+\operatorname{apamin} 0.1$ \\
$\square-\mathrm{TCA}$ & $-\mathrm{TCA}+\operatorname{apamin} 0.5$ \\
$-\mathrm{TCA}+$ apamin 0.01 & $-\mathrm{TCA}+$ apamin 1 \\
$-\mathrm{TCA}+$ apamin 0.05 & \\
\hline
\end{tabular}

Fig. 4. Prevention of analgesia induced by amitriptyline (15 mg kg-1 s.c.) and clomipramine $\left(25 \mathrm{mg} \mathrm{kg}^{-1}\right.$ s.c.) by increasing concentrations of apamin (0.01-1 ng per mouse i.c.v.) in the mouse hot-plate test. Mice were i.c.v. injected 15 min before the test. Vertical lines give SEM; there were 11-18 mice per group. $* p<0.05$ in comparison with corresponding analgesic drug-treated mice. Inset: dose-dependent prevention of amitriptyline (15 $\mathrm{mg} \mathrm{kg} \mathrm{k}^{-1}$ s.c., panel A) and clomipramine $\left(25 \mathrm{mg} \mathrm{kg}^{-1}\right.$ s.c., panel B) analgesia by increasing concentrations of apamin.

(Hille, 1994). The $\mathrm{K}_{\mathrm{ATP}}$ channels can be opened through a mechanism mediated by G-proteins. It has been reported that the interaction between the $\alpha$-GTP subunit and the $\mathrm{K}_{\mathrm{ATP}}$ channel produces a conformational change that stimulates the opening of the channel (Edwards and Weston, 1993). In the presence of GTP $\gamma \mathrm{S}$, a nonhydrolysable GTP analogue, an irreversible activation of
$\mathrm{K}_{\text {AтP }}$ is obtained. Furthermore, the $\alpha$ subunits involved in the modulation of $\mathrm{K}_{\mathrm{ATP}}$ channel function have been identified as belonging to the $\alpha_{i}$ and $\alpha_{o}$ subtypes (Edwards and Weston, 1993). From this evidence, we can suppose that $\mathrm{K}_{\mathrm{ATP}}$ channels are involved in the analgesia induced by amitriptyline and clomipramine as an intracellular effector underlying the activation of a $G_{i}$ 
Table 1

Effect of potassium channel modulators in the mouse hot-plate test ${ }^{\mathrm{a}}$

\begin{tabular}{|c|c|c|c|c|c|}
\hline \multirow[t]{3}{*}{ Treatment (i.c.v.) } & \multicolumn{5}{|l|}{ Licking latency (s) } \\
\hline & \multirow[t]{2}{*}{ Before treatment } & \multicolumn{4}{|c|}{ After treatment } \\
\hline & & $15 \min$ & $30 \mathrm{~min}$ & $45 \min$ & $60 \mathrm{~min}$ \\
\hline SALINE & $15.9 \pm 0.8$ & $15.2 \pm 0.7$ & $15.0 \pm 0.9$ & $14.8 \pm 0.9$ & $14.4 \pm 0.8$ \\
\hline GLIQ $1 \mu \mathrm{g}$ & $15.2 \pm 1.0$ & $14.2 \pm 1.2$ & $14.9 \pm 1.0$ & $15.2 \pm 1.5$ & $14.4 \pm 1.3$ \\
\hline APA $1 \mathrm{ng}$ & $16.0 \pm 1.4$ & $15.2 \pm 1.0$ & $14.2 \pm 1.4$ & $14.0 \pm 1.1$ & $14.9 \pm 1.5$ \\
\hline MIN $10 \mu \mathrm{g}$ & $15.8 \pm 1.3$ & $15.9 \pm 1.5$ & $14.3 \pm 0.9$ & $14.5 \pm 1.4$ & $14.3 \pm 1.1$ \\
\hline TEA $0.5 \mu \mathrm{g}$ & $15.6 \pm 1.2$ & $14.7 \pm 1.1$ & $15.0 \pm 1.3$ & $14.8 \pm 1.3$ & $14.2 \pm 1.0$ \\
\hline VEHICLE & $15.3 \pm 1.6$ & $14.5 \pm 1.0$ & $14.7 \pm 1.1$ & $14.3 \pm 0.9$ & $14.5 \pm 0.6$ \\
\hline PIN $25 \mu \mathrm{g}$ & $15.5 \pm 1.2$ & $14.8 \pm 0.9$ & $15.5 \pm 1.6$ & $15.1 \pm 1.4$ & $14.6 \pm 0.9$ \\
\hline
\end{tabular}

a GLIQ: gliquidone; APA: apamin; MIN: minoxidil; TEA: tetraethylammonium; PIN: pinacidil. Data are reported as mean \pm SEM; vehicle $=\mathrm{H}_{2} \mathrm{O}+\mathrm{DMSO}(3: 1)$.

Table 2

Effect of clomipramine, amitriptyline, TEA, apamin, gliquidone, minoxidil and pinacidil in the mouse rota-rod test ${ }^{\mathrm{a}}$

\begin{tabular}{|c|c|c|c|c|}
\hline \multirow[t]{3}{*}{ Treatment } & \multicolumn{4}{|l|}{ Endurance time (s) } \\
\hline & \multirow[t]{2}{*}{ Before treatment } & \multicolumn{3}{|c|}{ After treatment } \\
\hline & & $15 \min$ & $30 \mathrm{~min}$ & $45 \mathrm{~min}$ \\
\hline SALINE & $104.1 \pm 7.3$ & $101.8 \pm 8.2$ & $111.4 \pm 7.0$ & $107.8 \pm 8.2$ \\
\hline AMI (15 mg kg ${ }^{-1}$ s.c. $)$ & $108.9 \pm 7.5$ & $99.6 \pm 7.2$ & $104.2 \pm 8.4$ & $101.6 \pm 7.4$ \\
\hline AMI (30 mg kg-1 s.c.) & $109.6 \pm 6.5$ & $39.2 \pm 8.5^{\mathrm{b} *}$ & $36.2 \pm 9.4 *$ & $67.6 \pm 7.4^{*}$ \\
\hline CLO (25 mg kg ${ }^{-1}$ s.c.) & $112.6 \pm 7.1$ & $101.2 \pm 8.5$ & $108.0 \pm 9.6$ & $110.1 \pm 7.6$ \\
\hline CLO (45 $\mathrm{mg} \mathrm{kg}^{-1}$ s.c.) & $107.4 \pm 6.2$ & $82.8 \pm 10.4$ & $63.6 \pm 8.4^{*}$ & $93.5 \pm 7.6$ \\
\hline TEA $(0.5 \mu$ i.c.v. $)$ & $113.6 \pm 6.4$ & $102.1 \pm 7.1$ & $111.1 \pm 6.4$ & $110.5 \pm 07.2$ \\
\hline APA (1 ng i.c.v.) & $105.8 \pm 7.0$ & $100.1 \pm 7.5$ & $108.4 \pm 7.9$ & $101.0 \pm 8.3$ \\
\hline GLIQ (1 $\mu$ g i.c.v.) & $103.4 \pm 7.4$ & $99.8 \pm 8.3$ & $101.0 \pm 7.4$ & $110.8 \pm 7.2$ \\
\hline MIN (10 $\mu$ g i.c.v.) & $106.6 \pm 7.0$ & $111.9 \pm 8.4$ & $105.9 \pm 7.3$ & $110.6 \pm 7.2$ \\
\hline VEHICLE & $107.5 \pm 7.5$ & $102.7 \pm 8.2$ & $112.3 \pm 7.5$ & $111.5 \pm 6.4$ \\
\hline PIN (25 $\mu$ g i.c.v.) & $103.8 \pm 6.3$ & $109.3 \pm 7.4$ & $100.1 \pm 8.6$ & $105.8 \pm 7.3$ \\
\hline
\end{tabular}

\footnotetext{
${ }^{a}$ CLO: clomipramine; AMI: amitriptyline; TEA: tetraethylammonium; APA: apamin; GLIQ: gliquidone; MIN: minoxidil; PIN: pinacidil. Data are reported as mean \pm SEM; vehicle: $\mathrm{H}_{2} \mathrm{O}+$ DMSO 3:1.

b $* p<0.05$ in comparison with saline-treated group.
}

protein. It is interesting to note that, in addition to the present results concerning tricyclic antisepressants, $\mathrm{K}_{\mathrm{ATP}}$ channel blockers also prevented the antinociception induced by other compounds which interact with $\mathrm{G}_{\mathrm{i}}$ protein-coupled receptors, such as $\mu$ - and $\delta$-opioid receptors, adenosine $A_{1}$ receptors, histamine $H_{1}$ receptors, $\alpha_{2}$ adrenoceptors (Ocaña et al., 1990; Wild et al., 1991; Ocaña and Baeyens, 1994; Ghelardini et al., 1998; Galeotti et al., 1999). Taken together, these data indicate that the opening of $\mathrm{K}_{\mathrm{ATP}}$ channels is a signal transduction mechanism common to analgesic drugs interacting with $\mathrm{G}_{\mathrm{i}}$ proteins.

The present study also provides evidence for the involvement of $\mathrm{Ca}^{2+}$-gated $\mathrm{K}^{+}$channels in the antinociception induced by tricyclic antidepressants. The i.c.v. administration of the bee venom apamin, a blocker of small (low) conductance $\mathrm{Ca}^{2+}$-gated $\mathrm{K}^{+}$channels (Rudy,
1988), prevented the analgesia produced by amitriptyline and clomipramine indicating the important role of $\mathrm{Ca}^{2+}$ gated $\mathrm{K}^{+}$channels in the modulation of the pain threshold produced by tricyclic antidepressants. TEA has been reported to block not only voltage-dependent but also $\mathrm{Ca}^{2+}$-activated $\mathrm{K}^{+}$channels (Cook and Quast, 1990; Halliwell, 1990). The prevention of amitriptyline and clomipramine antinociception by TEA administration further supports the hypothesis of a $\mathrm{Ca}^{2+}$-gated $\mathrm{K}^{+}$channel role in the mechanism of analgesic action of tricyclic antidepressants. These results are not in agreement with previous data which reported that amitriptyline was a weak inhibitor (20\% inhibition) of the large conductance $\mathrm{Ca}^{2+}$-activated $\mathrm{K}^{+}$channel $\left(\mathrm{BK}_{\mathrm{Ca}}\right)$ activity in rat isolated cortical neurones (Lee et al., 1997). However, this discrepancy could be explained by considering that these inhibitory effects were not identified as part of the mech- 
A

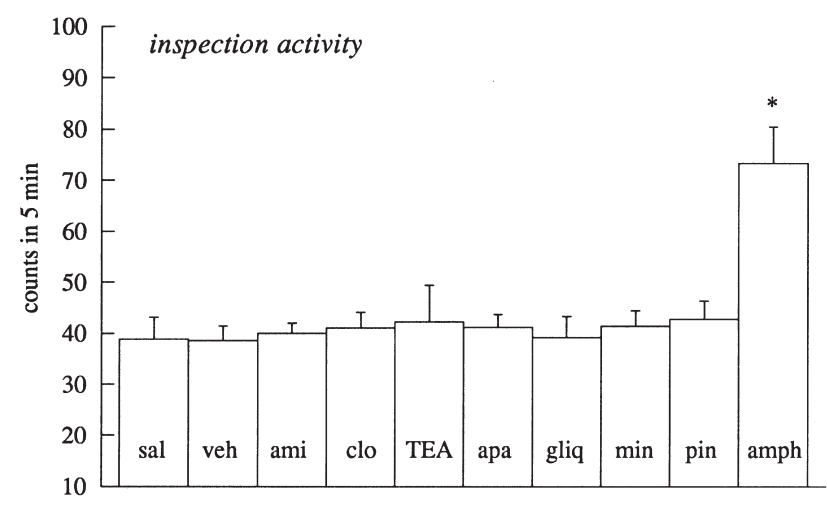

B

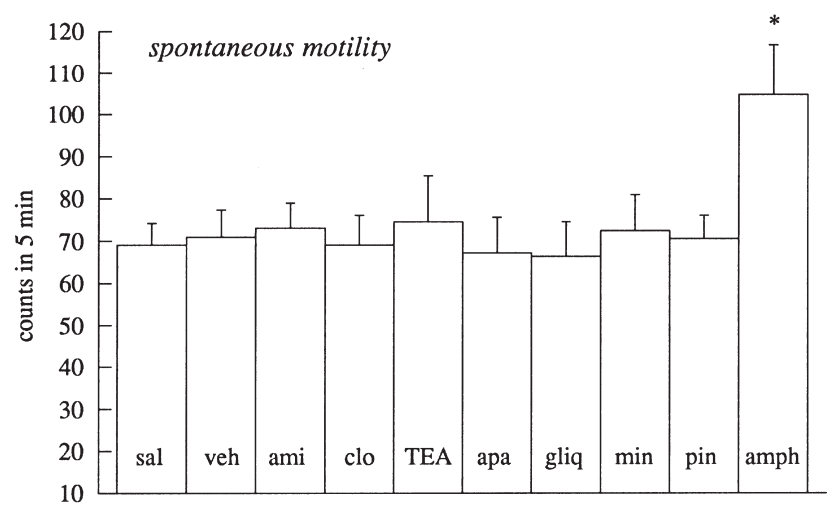

Fig. 5. Effect of amitriptyline ( $15 \mathrm{mg} \mathrm{kg}^{-1}$ s.c.), clomipramine (25 $\mathrm{mg} \mathrm{kg}^{-1}$ s.c.), TEA (0.5 $\mu$ g per mouse i.c.v.), apamin (1 ng per mouse i.c.v.), gliquidone ( $1 \mu \mathrm{g}$ per mouse i.c.v.), minoxidil (10 $\mu \mathrm{g}$ per mouse i.c.v.), pinacidil ( $25 \mu \mathrm{g}$ per mouse i.c.v.) in the mouse hole-board test. The number of movements was detected $30 \mathrm{~min}$ after administration of all drugs with the exception of D-amphetamine which was injected $15 \mathrm{~min}$ before the test. D-Amphetamine ( $2 \mathrm{mg} \mathrm{kg}^{-1}$ s.c.) was used as reference drug. Vertical lines give SEM; there were 9-12 mice per group. $* p<0.01$ in comparison with saline-treated mice.

anism of antidepressant action, but this activity was supposed to contribute to the induction of side effects associated with tricyclic compound therapy (Lee et al., 1997). It should also be noted that the doses of tricyclic antidepressants used for analgesia are lower than those considered effective in the treatment of depression (Acton et al., 1992). It seems, unlikely therefore, that, at analgesic doses, inhibitory actions on $\mathrm{Ca}^{2+}$-gated $\mathrm{K}^{+}$ channels, which represent undesirable side effects associated with high dosage antidepressant therapy, could appear.

The complete reversion of TCAs analgesia exerted by the blockers of different types of potassium channels is difficult to explain. In fact, it would be expected that each blocking drug would only partially reverse the effect of TCAs. However, even if we do not have any convincing explanation for this particular effect, we can assess that this is a general phenomenon produced by potassium channel modulators. Potassium channel blockers may increase the excitability of central circuits so that, when pain responses are generated and these circuits fire, one can overcome the antinociceptive activity of TCAs by increasing the excitability of the system. Likewise, $\mathrm{K}_{\text {АтP }}$ openers would decrease the excitability of central circuits by hyperpolarising cellular membranes. However, the system is so complex that other explanations could exist.

Amitriptyline and clomipramine exerted their antinociceptive activity without showing any alteration of the motor coordination of the mice as revealed by the rotarod test. Furthermore, the tricyclic antidepressants did not modify the spontaneous motility and inspection activity as revealed by the hole board test. However, the administration of doses of amitriptyline and clomipramine two times higher than those used in the present study produced impairment of motor coordination whose appearance could lead to a modification of the licking latency values detected in the hot-plate test. In order to avoid misinterpretation of data, it has been necessary to limit the investigation to doses of amitriptyline and clomipramine at which these compounds showed antinociceptive properties without any behavioural side effect.

The potassium channel modulators, at the highest doses used, did not modify the gross behaviour of the animals. Moreover, these compounds did not impair motor coordination as revealed by the rota rod test nor modify locomotor and inspection activity as indicated by the hole board test. Therefore, we can suppose that the effects produced by potassium channel modulators cannot be attributed to compromised behavioural paradigms. Regarding the potassium channel blockers TEA and apamin, doses twice those able to completely prevent TCAs analgesia, induced convulsions in mice.

In conclusion, the present data demonstrate that neuronal $\mathrm{K}^{+}$channels represent an important intracellular effector in the antinociceptive activity of tricyclic antidepressants. The modulation of voltage-gated, $\mathrm{K}_{\mathrm{ATP}}$ and $\mathrm{Ca}^{2+}$-gated $\mathrm{K}^{+}$channels is, in fact, able to modulate the capability of amitriptyline and clomipramine to induce analgesia.

\section{Acknowledgements}

This work was supported by grants from MURST.

\section{References}

Acton, J., Mckenna, J.E., Melzack, R., 1992. Amitriptyline produces analgesia in the formalin pain test. Experimental Neurology 117, 94-96.

Amoroso, S., Schmidt-Antomarchi, H., Fosset, M., Lazdunski, M., 1990. Glucose, sulphonylureas, and neurotransmitter release: role of ATP-sensitive $\mathrm{K}^{+}$channels. Science 247, 852-854. 
Bobker, D.H., Williams, J.T., 1990. Ion conductance affected by 5-HT receptor subtypes in mammalian neurones. Trends in Neuroscience 13, 169-173.

Brown, A.M., Birnbaumer, L., 1990. Ionic channels and their regulation by $\mathrm{G}$ protein subunits. Annual Reviews of Physiology 52, 197-213.

Brown, D.A., 1990. G-proteins and potassium currents in neurones. Annual Reviews of Physiology 52, 215-242.

Catterall, W.A., 1988. Structure and function of voltage-sensitive ion channels. Science 242, 50-61.

Christie, M.J., 1995. Molecular and functional diversity of $\mathrm{K}^{+}$channels. Clinical and Experimental Pharmacology and Physiology 22, 944-951.

Cook, N.S., 1988. The pharmacology of potassium channels and their therapeutic potential. Trends in Pharmacological Science 9, 21-28.

Cook, N.S., Quast, U., 1990. Potassium channel pharmacology. In: Cook, N.S. (Ed.), Potassium Channels: Structure, Classification, Function and Therapeutic Potential. Ellis Horwood, Chichester, UK, pp. 181-255.

Edwards, G., Weston, A.H., 1993. The pharmacology of ATP-sensitive potassium channels. Annual Reviews of Pharmacology and Toxicology 33, 597-637.

Galeotti, N., Ghelardini, C., Bartolini, A., 1995. Involvement of the serotoninergic system in the analgesic effect of tricyclic antidepressants. Behavioural Pharmacology 6 (Suppl. 1), 20.

Galeotti, N., Ghelardini, C., Bartolini, A., 1996. Effect of pertussis toxin on morphine, diphenhydramine, baclofen, clomipramine and physostigmine antinociception. European Journal of Pharmacology 308, 125-133.

Galeotti, N., Ghelardini, C., Capaccioli, S., Quattrone, A., Bartolini, A., 1997. Blockade of clomipramine and amitriptyline analgesia by an antisense oligonucleotide to $\mathrm{mKv1.1,} \mathrm{a} \mathrm{mouse} \mathrm{Shaker-like}$ potassium channel. European Journal of Pharmacology 330, 15-25.

Galeotti, N., Ghelardini, C., Vinci, M.C., Bartolini, A., 1999. Role of potassium channels in the antinociception induced by agonists of $\alpha_{2}$-adrenoceptors. British Journal of Pharmacology 126, 1214 1220.

Ghelardini, C., Galeotti, N., Caldari, B., Vinci, M.C., Bartolini, A., 1998. Involvement of $\mathrm{K}_{\mathrm{ATP}}$ and $\mathrm{Ca}^{++}$-gated potassium channels in the antinociception induced by $\mathrm{H}_{1}$-antihistaminics. In: International Meeting on Biomedicine, Florence, Italy, November 25-27., p. 125.

Goldstein, F.J., Malseed, R.J., Nutz, J.F., 1990. Effect of chronic clomipramine on central DADLE antinociception. Pain 42, 331-336.

Haley, T.J., McCormick, W.G., 1957. Pharmacological effects produced by intracerebral injection of drugs in the conscious mouse. British Journal of Pharmacology and Chemotherapy 12, 12-15.

Halliwell, J.V., 1990. $\mathrm{K}^{+}$channels in the central nervous system. In: Cook, N.S. (Ed.), Potassium Channels: Structure, Classification, Function and Therapeutic Potential. Ellis Horwood, Chichester, UK, pp. 348-381.

Hille, B., 1994. Modulation of ion-channel function by G-proteincoupled receptors. Trends in Neuroscience 17, 531-536.

Jan, L.Y., Jan, Y.N., 1989. Voltage-sensitive ion channels. Cell 56, $13-25$.

Kuribara, H., Higuchi, Y., Takadoro, S., 1977. Effects of central depressants on rota-rod and traction performances in mice. Japanese Journal of Pharmacology 27, 117-126.

Lee, K., Mckenna, F., Rowe, I.C.M., Ashford, M.L.J., 1997. The effects of neuroleptic and tricyclic compounds on $\mathrm{BK}_{\mathrm{Ca}}$ channel activity in rat isolated cortical neurones. British Journal of Pharmacology 121, 1810-1816.
Longman, S.D., Hamilton, T.C., 1992. Potassium channel activator drugs: mechanism of action, pharmacological properties, and therapeutic potential. Medical Research Reviews 12, 73-148.

Mathie, A., Wooltorton, J.R.A., Watkins, C.S., 1998. Voltage-activated potassium channels in mammalian neurones and their block by novel pharmacological agents. General Pharmacology 30, 13-24.

Murua, V.S., Molina, V.A., 1991. Chronic antidepressant counteracts the conditioned analgesia induced by a context previously associated with inescapable shock. Psychopharmacology 105, 439-441.

Narita, M., Takamori, K., Kawashima, N., Funada, M., Kamei, J., Suzuki, T., Misawa, M., Nagase, H., 1993. Activation of central ATP-sensitive potassium channels produces the antinociception and spinal noradrenaline turnover-enhancing effect in mice. Psychopharmacology 113, 11-14.

O'Callaghan, J.P., Holtzman, S.G., 1975. Quantification of the analgesic activity of narcotic antagonists by a modified hot-plate procedure. Journal of Pharmacology and Experimental Therapeutics 192, 497-505.

Ocaña, M., Baeyens, J.M., 1993. Differential effect of $\mathrm{K}^{+}$channel blockers on antinociception induced by $\alpha_{2}$-adrenoceptor, $\mathrm{GABA}_{\mathrm{B}}$ and $\kappa$-opioid receptor agonists. British Journal of Pharmacology 110, 1049-1054.

Ocaña, M., Baeyens, J.M., 1994. Role of ATP-sensitive $\mathrm{K}^{+}$channels in antinociception induced by R-PIA, an adenosine $\mathrm{A}_{1}$ receptor agonist. Naunyn-Schmiedeberg's Archives of Pharmacology 350, $57-62$

Ocaña, M., Barrios, M., Baeyens, J.M., 1996. Cromakalim differentially enhances antinociception induced by agonists of alpha $\mathrm{adre}_{2}$ noceptors, $\gamma$-aminobutyric acid $_{\mathrm{B}}, m u$ and kappa opioid receptors. Journal of Pharmacology and Experimental Therapeutics 276, $1136-1142$.

Ocaña, M., Del Pozo, E., Barrios, M., Robles, L.I., Baeyens, J.M., 1990. An ATP-dependent potassium channel blocker antagonises morphine analgesia. European Journal of Pharmacology 186, 377-378.

Raffa, R.B., Martinez, R.P., 1995. The glibenclamide shift of centrallyacting antinociceptive agents in mice. Brain Research 677, $277-$ 282.

Richeimer, S.H., Bajwa, Z.H., Kahraman, S.S., Ransil, B.J., Warfield, C.A., 1997. Utilisation patterns of tricyclic antidepressants in a multidisciplinary pain clinic: a survey. Clinical Journal of Pain 13, 324-329.

Rudy, B., 1988. Diversity and ubiquity of K channels. Neuroscience 25, 729-749.

Sacerdote, P., Brini, A., Mantegazza, P., Panerai, A.E., 1987. A role for serotonin and beta-endorphin in the analgesia induced by some tricyclic antidepressant drugs. Pharmacological and Biochemical Behaviour 26, 153-158.

Vergoni, A.V., Scarano, A., Bertolini, A., 1992. Pinacidil potentiates morphine analgesia. Life Science 50, PL135-PL138.

Welch, S.P., Dunlow, L.D., 1993. Antinociceptive activity of intrathecally administered potassium channel openers and opioid agonists, a common mechanism of action? Journal of Pharmacology and Experimental Therapeutics 267, 390-399.

Welch, S.P., Thomas, C., Patrick, G.S., 1995. Modulation of cannabinoid-induced antinociception after intracerebroventricular versus intrathecal administration to mice: possible mechanisms for interaction with morphine. Journal of Pharmacology and Experimental Therapeutics 272, 310-321.

Wild, K.D., Vanderah, T., Mosberg, H.I., Porreca, F., 1991. Opioid $\delta$ receptor subtypes are associated with different potassium channels. European Journal of Pharmacology 193, 135-136. 